\title{
Organic matter amendments improve soil fertility in almond orchards of contrasting soil texture
}

\author{
Yocelyn B. Villa - Sat Darshan S. Khalsa - Rebecca Ryals • Roger A. Duncan • \\ Patrick H. Brown · Stephen C. Hart
}

Received: 29 September 2020/ Accepted: 7 June 2021 / Published online: 24 June 2021

(C) The Author(s) 2021

\begin{abstract}
The effects of organic matter amendments (OMA) on soil fertility in permanent cropping systems like orchards is under-studied compared to annual cropping systems. We evaluated experimentally the impact of OMAs on soil fertility in almond (Prunus dulcis) orchards over a two-year period with annual applications. Two OMAs, derived from composted green waste (GWC) or composted manure wood chips (MWC), were applied as surface mulch and compared to a control at two sites with different soil textures (sandy loam and loamy sand). OMAs increased soil
\end{abstract}

Supplementary Information The online version contains supplementary material available at https://doi.org/10.1007/ s10705-021-10154-5.

\section{Y. B. Villa $(\bowtie)$}

Environmental Systems Graduate Group, University of California, Merced, CA, USA

e-mail: yvilla3@ucmerced.edu

S. D. S. Khalsa · P. H. Brown

Department of Plant Sciences, College of Agricultural and Environmental Sciences, University of California, Davis, CA, USA

R. Ryals - S. C. Hart

Department of Life and Environmental Sciences and Sierra Nevada Research Institute, University of

California, Merced, CA, USA

R. A. Duncan

University of California Cooperative Extension, Modesto, CA, USA moisture content $(0-0.1 \mathrm{~m}$ depth) at both sites by 27-37\%. Both amendments increased soil inorganic $\mathrm{N}$ at the sandy loam (GWC: 194\%; MWC: 114\%) and loamy sand (GWC: 277\%; MWC: 114\%) sites the month following application, but soil inorganic $\mathrm{N}$ concentrations quickly decreased to values similar to those of control plots. After two-years, the GWC and the MWC amendments increased the soil cation exchange capacity (CEC) by $112 \%$ and $29 \%$, respectively, in the sandy loam site, but no change was observed in the loamy sand site. The greatest increase in soil extractable $\mathrm{K}$ occurred in the GWC-amended plots at the sandy loam site even though the initial $\mathrm{K}$ concentration of MWC was higher. Both OMAs increased soil organic carbon (SOC) after two years, but the SOC increase in the GWC-amended plots was greater. Our results suggest that OMAs can significantly improve soil fertility after one or two annual applications, and that fertility gains appear to be dependent on soil texture than the nutrient concentrations of the OMA.

Keywords Cation exchange capacity - Composted manure $\cdot$ Decomposition $\cdot$ Green waste $\cdot$ Nutrient dynamics $\cdot$ Perennial crops 


\section{Introduction}

Abundant sources of organic matter in the Central Valley, such as green wastes from agriculture and urban areas and manures from dairy production, can help augment soil organic matter (SOM) levels in permanent crops like almond orchards (Khalsa and Brown 2017). Typically, SOM levels in California's Central Valley soils range from 0.5 to $2.5 \%$ (Warren 1996). Permanent crops like almonds planted on 562,525 ha are a prime candidate for the application of organic matter amendments (OMAs). In this region, $82 \%$ of the world's almonds are produced (Almond Almanac 2018). Although almond trees generally grow best in sandy soils, expansion of almond orchard into soil types with higher silt and clay content has become more common. A poor understanding of how to manage OMAs in orchards limits their use and weakens the potential for improvement in soil fertility in these agroecosystems (Khalsa and Brown 2017). Although there have been many studies that have focused on the effects of OMAs in row crops and permanent crops in other regions, few have focused on how these amendments affect soil fertility in permanent crops in California (Baldi et al. 2018; Blackshaw et al. 2005; Canali et al. 2004; Forge et al. 2013; Gannett et al. 2019; Lepsch et al. 2019; Peck et al. 2011). Understanding how surficial applications of OMAs influence nutrient dynamics in the short-term in permanent cropping systems poses different challenges than in annual cropping systems where OMAs are incorporated directly into the soil (Jackson et al. 2003).

Farmers and growers use many practices that promote soil fertility, minimize water use, and lower nutrient losses from the field. An example of this is the capture, conversion, and reuse of organic wastes as OMAs to agricultural soils. Sources of organic wastes include livestock manures, food waste, yard debris, and biosolids. These materials are rich in nutrients and organic matter that could be recycled back to the soil, improve soil fertility, and minimize environmental consequences of landfilling or other waste management fates. Composting organic wastes prior to land application slows the rate of decomposition and nutrient release compared to the organic wastes in their raw, undecomposed form (Hue and Liu 1995). There is increased opportunity to recover and reuse organic wastes by applying these materials to agricultural soils as composted OMAs due to new policy incentives aimed at improving soil fertility and enhancing soil carbon (C) sequestration. For example, the state of California recently passed several pieces of legislation aimed at diverting organics from landfills and increasing composting (e.g., SB 1383, AB 1594, Healthy Soils). Improper disposal of these organic wastes can cause detrimental environmental effects such as increased greenhouse gas emissions and water and air pollution (Borjesson and Katterer 2018; Brown et al. 2011). Composting can minimize these negative impacts and also build productive soils through the introduction of exogenous organic matter.

Composts can be comprised of different organic materials that may also experience diverse composting processes that affect their physical state (e.g., particle size) and chemical composition. Composting involves biological decomposition that transform heterogeneous organic waste under relatively controlled environmental conditions of moisture, temperature, and aeration to more homogeneous organic matter (Acatrinei et al. 2019). Variations of these conditions change the end product of the composted OMAs, which influences the subsequent decomposition of the applied material and their impact on soils processes (Diacono and Montemurro 2010). Additionally, the carbon to nitrogen $(\mathrm{C}: \mathrm{N})$ ratio of the initial and final organic material influences the persistence of the OMA and subsequent release of nutrients available for plant uptake (Hue and Liu 1995; Diacono and Montemurro 2010; Feng et al. 2013; Leon et al. 2015; Liu and Zhou 2017; Nicholson et al. 2018).

Soil texture may mediate the impacts of OMAs on soil fertility. Soils with a higher clay fraction tend to have a greater proportion of micropores to store plantavailable water than soils with coarser soil texture. The greater specific surface area and negative charge density of clay-sized soil separates also lead to greater capacity for nutrient storage (Sarker et al. 2018). Furthermore, soils with higher clay content tend to exhibit higher SOM persistence due to the physical interactions of these particles with SOM (Paul 2016; Torn et al. 1997). Hence, soils with higher clay content are typically higher in SOM content, store greater amounts of plant available water and nutrients, and are less susceptible to nutrient loss via leaching than soils with coarser textures (Diacono and Montemurro 2010; Ding et al. 2014; Sarker et al. 2018). In coarser textured soils, OMAs applied to row crops have been 
shown to improve soil chemical and physical properties, such as increases in soil water holding capacity, aggregate stability, and cation exchange capacity (CEC; Ozores-Hampton et al. 2011). Application of OMAs to finer textured soils may increase the relative abundance of macropores, improving aeration, water infiltration, and soil aggregation. Regardless of soil texture, the resultant changes in soil pore size distribution from OMA addition typically lead to greater plant available soil water storage (Eusufzai and Fujii 2012).

We determined how the application of two different OMAs influences soil fertility in two almond orchards with contrasting textures. We focused on soil measurements in our study because the almond tree were not of fruit bearing age. We hypothesized that: (1) the manure wood chip compost (MWC) will decompose and release nutrients to the soil more slowly than green waste compost (GWC) because of the higher initial C:N ratio of MWC; (2) OMA additions will improve soil moisture content because organic matter increases water holding capacity by improving soil physical properties; (3) the application of both OMAs would increase total $\mathrm{C}$, total nitrogen $(\mathrm{N})$, extractable potassium $(\mathrm{K})$, and plant-available $\mathrm{N}$ and phosphorus $(\mathrm{P})$ in both soils; and (4) OMA application to coarser textured soil (loamy sand) would increase the soil CEC to a greater relative extent than the finer textured (sandy loam) soil because of the former having an inherently lower CEC. We evaluated these hypotheses in two almond orchards of contrasting textures that received annual applications of GWC and MWC over a two-year period.

\section{Materials and methods}

Study sites

We conducted this study in two almond orchards approximately $8 \mathrm{~km}$ from each other near Modesto, California $\left(37.71^{\circ} \mathrm{N},-120.95^{\circ} \mathrm{W}\right.$ and $37.73^{\circ} \mathrm{N}$, $-121.01^{\circ} \mathrm{W} ; 27 \mathrm{~m}$ above sea level), over two growing seasons (February 2016 through February 2018). Soils in the region are developed from granitic alluvium (Storie and Weir 1953). Soils in the first orchard are classified as fine, smectitic, thermic Abruptic Durixeralfs USDA Soil Taxonomic family, and have a sandy loam surface soil texture (in the
0-0.5 m soil depth (mean \pm standard error, $\mathrm{n}=4$ ): $57 \pm 1.1 \%$ sand, $33 \pm 1.1 \%$ silt, $10 \pm 0.1 \%$ clay), determined using the hydrometer method as described in Gee and Bauder (1986). Soil pH was determined to be $7.37 \pm 0.05$ measured in an 1:2 soil to deionized water (w/v) suspension (McLean 2015) for the 0-0.5 m soil depth (mean \pm standard error, $n=4$ ). This orchard will be referred to hereafter as the "Loam site." The soils in the second orchard are classified as mixed, thermic Typic Xeropsamments, and have a loamy sand surface $(0-0.5 \mathrm{~m})$ soil texture $(89 \pm 0.2 \%$ sand, $7 \pm 0.4 \%$ silt, $4 \pm 0.4 \%$ clay) with a $\mathrm{pH}$ of $7.82 \pm 0.06$. This orchard will be referred to hereafter as the "Sand site." Mean annual precipitation in this region (failing entirely as rain) is $335 \mathrm{~mm}$ and mean annual air temperature is $17.5^{\circ} \mathrm{C}$.

\section{Experimental design}

The almond trees in the Loam orchard were the cultivar 'Nonpareil' and in the Sand site the trees were the cultivar 'Independence'. The current trees occupying both orchards were planted in 2013 and at the time of the study, were not producing fruit. Soils were tilled before tree planting. Experimental controls never received any OMA, only inorganic fertilizers. Immediately prior to establishment of the current almond orchards, the Loam site was a fallowed field and the Sand site was an older almond orchard. At the beginning of this study, trees were approximately $1.5 \mathrm{~m}$ tall with a tree trunk circumference at breast height $(1.4 \mathrm{~m})$ of $0.5 \mathrm{~m}$. Both almond orchards are irrigated using micro-sprinklers at a rate of 20,860 $\mathrm{mm} \mathrm{yr}^{-1}$ and were fertilized with urea ammonium nitrate (UAN) $32 \% \quad \mathrm{~N}$ at a rate of $139 \mathrm{~kg} \mathrm{~N} \mathrm{ha}^{-1} \mathrm{yr}^{-1}$ in 2016, and $207 \mathrm{~kg} \mathrm{~N} \mathrm{ha}^{-1}$ $\mathrm{yr}^{-1}$ in 2017. At each site, fertilizer was applied via irrigation three times during the growing season for both years: in late February before compost application, in mid-June, and late July. OMAs were applied to the soil surface in a $1.2 \mathrm{~m}$ band at $11,570 \mathrm{~kg} \mathrm{ha}^{-1}$ (Loam site) or $18,160 \mathrm{~kg} \mathrm{ha}^{-1}$ (Sand site) prior to planting. OMAs were incorporated into the planting berm when trees were machine-planted in January 2013. Subsequently, OMAs were placed on the soil surface near each tree $\left(1230 \mathrm{~kg} \mathrm{ha}^{-1}\right.$ at both sites) in May 2015. Both OMAs were applied again to the soil surface in late February-early March in 2016 
$\left(28,020 \mathrm{~kg} \mathrm{ha}^{-1}\right)$ and $2017\left(26,900 \mathrm{~kg} \mathrm{ha}^{-1}\right)$, concentrated in a $3 \mathrm{~m}$ band down the tree rows.

Experimental treatments included two types of OMA, manure wood chip compost (MWC) and green waste compost (GWC), as well as an unamended control. Although the two OMAs each year were obtained from the same suppliers (GWC: Recology Premium Compost ${ }^{\circledR}$ from Recology Organics, Vernalis, CA, USA; MWC: product from Epic Soils, Oakdale, CA, USA), the initial elemental composition of the same OMA type applied differed between years (Table 1). Treatment plots were established in the almond orchards using a randomized block design ( $n=4$ at the Loam site and $n=5$ at the Sand site; Supplemental Fig. 2). In the loam site, each treatment plot consisted of 12 almond trees in a row; trees were spaced $4.9 \mathrm{~m}$ apart within the row and rows were planted $6.7 \mathrm{~m}$ apart. At the Sand site, each block was 15 trees long; trees were spaced $4.3 \mathrm{~m}$ apart and rows were $6.4 \mathrm{~m}$ apart. The Loam site planted with 'Nonpareil' had four plots, separated by a row of pollinizer cultivars 'Wood Colony' and 'Aldrich'. Plots in the Sand site planted with 'Independence' were adjacent to each other as no pollinizer is required for this self-fertile variety (Supplemental Fig. 2). Hobo soil thermometers were deployed at $0.1 \mathrm{~m}$ from the soil surface $(\mathrm{n}=9$ each site, total $n=18$ ). Each treatment had three thermometers per site for replication. Measurements were programed to record soil temperature every hour from the Spring of 2017 to Spring of 2018.

Decomposition rates and nutrient analysis of organic matter amendments

Initial compost samples from 2016 and 2017 were shipped to the UC Davis Analytical Laboratory for macro- and micro-nutrient analyses. Subsamples were digested using nitric acid/hydrogen peroxide microwave digestion and then analyzed on an Inductively Coupled Plasma Atomic Emission Spectrometry (ICP$\mathrm{AES}$ ) for total $\mathrm{P}, \mathrm{K}$, sulfur (S), calcium (Ca), magnesium $(\mathrm{Mg})$, iron $(\mathrm{Fe})$, boron $(\mathrm{B})$, copper $(\mathrm{Cu})$, manganese $(\mathrm{Mn})$, and zinc ( $\mathrm{Zn}$; Meyer and Keliher 1992; Sah and Miller 1992).

In both years, decomposition rates and nutrient release from MWC and GWC amendments were assessed using decomposition rings that consisted of $0.2 \mathrm{~m}$ tall, $0.1 \mathrm{~m}$ diameter PVC pipe, with a mesh screen $(0.794 \mathrm{~mm}$ openings) attached to the bottom.
Each decomposition ring was filled with $50 \mathrm{~g}$ fresh weight of either MWC or GWC to simulate field application and rate applied in the Spring of 2016 and 2017. Twenty-four rings were placed randomly within the rows, at least $1 \mathrm{~m}$ away from trees, in each MWC and GWC treatment plot, and secured to the ground using rebar tie wire. Some decomposition rings were physically lost $(\sim 12)$, while the data from some other decomposition rings were not used because of substantial contamination by mineral soil or unrealistic disappearance of organic matter from the decomposition ring (presumably due to disturbance by wind, animal activity, or agricultural machinery). Decomposition rings were also placed on top of each of the soil cores $(0-0.5 \mathrm{~m})$ in the MWC and GWC treatment plots (see Supplemental Fig. 1). Two decomposition rings were randomly collected $(n=8$ at the Loam site, $\mathrm{n}=10$ at the Sand site) and composited from each plot at approximately 30 day intervals during the two growing seasons. The samples were place on Rubbermaid Blue Ice ${ }^{\circledR}$ in a cooler, then transported back to the laboratory at the University of California (UC) Merced for gravimetric water content and chemical analyses. Although we originally planned to conclude this component of our study at twelve months, substantial mineral soil contamination occurred in most of the decomposition rings after nine months following the application of the OMAs, or all of the compost within a decomposition ring had disappeared presumably due to disturbance as noted above. Decomposition rings in the second year of this study had significant mineral contamination after only 4 months. Hence, we only used data collected from the first nine months during year one for determining $\mathrm{C}, \mathrm{N}, \mathrm{P}$, and $\mathrm{K}$ loss during OMA decomposition.

Field-collected MWC and GWC from decomposition rings were weighed (field-moist) within $24 \mathrm{~h}$ after collection. Approximately, $15 \mathrm{~g}$ fresh-weight subsamples were placed in a $105^{\circ} \mathrm{C}$ oven for $24 \mathrm{~h}$ to determine gravimetric water content and to calculate the dry-mass remaining in the ring. Air-dried GWC and MWC samples were coarsely ground through a 1-mm mesh screen using a large Thomas Wiley Model 4 Mill (Swedesboro, NJ, USA). Subsamples ( $\sim 4 \mathrm{~g}$ ) of these materials were then finely ground through a $420 \mu \mathrm{m}$ (40 mesh) screen using a Wiley Mini Mill. Finely ground samples were analyzed for total $\mathrm{C}$ and $\mathrm{N}-$ Combustion on a TruSpec $\mathrm{CN}$ Analyzer at UC Davis Analytical Laboratory. 
Decomposition rates of OMAs were calculated as the net decrease in $\mathrm{C}$ mass remaining over time. Similarly, the net release of N, P, and K from these materials during decomposition was estimated as the net decrease in the masses of these elements remaining in the OMA over time. Elemental masses were calculated by multiplying the oven-dry concentrations of the respective element by the oven-dry mass of OMA remaining.

\section{Plant available soil nutrients}

Plant available soil nutrients (nitrate, $\mathrm{NO}_{3}$; ammonium, $\mathrm{NH}_{4}{ }^{+}$; and phosphate, $\mathrm{PO}_{4}{ }^{3-}$ ) were determined in situ using ion exchange resin (IER) bags placed at the bottom of intact soil cores $(0.5 \mathrm{~m}$ in length) contained within solid $0.1 \mathrm{~m}$ diameter PVC pipes (a variation of the Resin-Core method where only the IER bags are analyzed; Binkley and Hart 1989; Supplemental Fig. 1). IER resin was placed at $0.5 \mathrm{~m}$ depth in order to capture nutrient availability in the active rooting zone, which has been determined to be from 0.2 to $0.6 \mathrm{~m}$ under micro-irrigation (Brown and Sanden unpublished data; Lepsch et al. 2019; Vrugt et al. 2001). Two PVC pipes were deployed within a treatment plot. Placement of the PVC pipes was determined by randomly selecting two locations within the row.

Resin-cores were harvested after one year (Feb. 2016-Feb. 2017), and the process was repeated for a second year (Feb. 2017-Feb. 2018). Harvested resin bags were transported in a cooler containing Blue Ice ${ }^{\circledR}$ for analysis at UC Merced. Resin beads were airdried, mixed, and a subsample of $15 \mathrm{~g}$ was extracted with $50 \mathrm{ml}$ of $2 \mathrm{M} \mathrm{KCl}$. Resin suspensions were shaken for one $\mathrm{h}$, then filtered with Whatman \#1 paper that was pre-leached with deionized water. Filtered extracts were then stored at $-20{ }^{\circ} \mathrm{C}$ until they were ready for analysis. Thawed extracts were mixed and then analyzed for $\mathrm{NO}_{3}{ }^{-}, \mathrm{NH}_{4}{ }^{+}$, and $\mathrm{PO}_{4}{ }^{3-}$ concentrations on a Lachat QuikChem 8500 Flow Injection Analyzer (Loveland, CO, USA) using methods 12-107-04-1-B, 12-107-06-1-B, and 10-115-01-1A, respectively. Available $\mathrm{N}$ and $\mathrm{P}$ over the two years were calculated by summing the total inorganic $\mathrm{N}$ and $\mathrm{PO}_{4}{ }^{3-}$, respectively, extracted from the resins collected in year one and year two, and expressing these data on an areal basis (using the cross-sectional area of the IER bag; $0.0078 \mathrm{~m}^{2}$ ). 
Soil analysis

Mineral soils (0-0.1 m depth) were collected every other month using an Oakfield soil probe (Oakfield, WI, USA; $0.17 \mathrm{~m}$ diameter) to determine soil inorganic N pool sizes. Soils were collected at this depth because OMA application is surface applied as a mulch and it has been determined that the active rooting zone is from 0.2 to $0.6 \mathrm{~m}$ under microirrigation (Brown and Sanden unpublished data; Lepsch et al. 2019; Vrugt et al. 2001). Two soil cores were taken randomly within a treatment block, composited, and then transported back to the laboratory at UC Merced in a cooler containing Blue Ice ${ }^{\circledR}$. Fresh soil was used to measure gravimetric soil moisture content $\left(105{ }^{\circ} \mathrm{C}\right.$ oven for $24 \mathrm{~h}$ ). A subsample of $15 \mathrm{~g}$ was shaken with $50 \mathrm{ml}$ of $2 \mathrm{M} \mathrm{KCl}$ for an hour then filtered using Whatman 1 filter paper. Soil extracts were frozen until ready for analysis on the Lachat QuikChem 8500 Flow Injection Analyzer (Loveland, CO, USA) using methods 12-107-04-1B for $\mathrm{NO}_{2} / \mathrm{NO}_{3}$ and 12-107-06-1-A for $\mathrm{NH}_{4}$, respectively. The remaining soil was air dried and used for fertility analyses.

Soils used for CEC and total organic C, N, and K were collected pre-application and after the second year of study. Sieved, air-dried soils were analyzed for cation exchange capacity (CEC) using the barium method (buffered to $\mathrm{pH}$ 7.0) at the UC Davis Analytical Laboratory (https://anlab.ucdavis.edu/ analysis/Soils/430; Rible and Quick 1960). Subsamples of air-dried were ground to a fine powder using a mortar and pestle and approximately $15 \mathrm{mg}$ of ground soil was weighed into tin capsules for total $\mathrm{C}$ and $\mathrm{N}$ analysis (Costech ECS 4010 CHNS-O Elemental Analyzer coupled with a ThermoFisher Delta-V Plus continuous flow isotope ratio mass spectrometer) at the UC Merced Stable Isotope Laboratory (https:// research.ucmerced.edu/core-facilities/stable-isotopelaboratory). Soils were corrected for air-dry moisture and no inorganic $\mathrm{C}$ was present as indicated by a lack of effervescence when $4 \mathrm{~N} \mathrm{HCl}$ was added to soils.

Statistical analysis

Initial characteristics of OMAs used in both years were analyzed using a one-way ANOVA with amendment type as a factor in the model, and a Tukey's multiple comparisons post hoc test was employed when ANOVA models were significant. Net release of $\mathrm{C}$ (i.e., decomposition), N, P, and K were analyzed separately using a two-way repeated measures ANOVA where OMA and site were factors for the model. Interactions of soil $\mathrm{NO}_{3}{ }^{-}$and $\mathrm{NH}_{4}{ }^{+}$from 0 to $0.1 \mathrm{~m}$ soil collected monthly were summed together to get total inorganic N, and were analyzed using a twoway repeated measures ANOVA to determine treatment and site effects through time. Additionally, total inorganic $\mathrm{N}$ data was split by site and analyzed using a two-way repeated measures ANOVA with treatment and month as factors. Available $\mathrm{N}$ and $\mathrm{P}$ from IER bags were analyzed using a three-way repeated measures ANOVA with treatment, site, and year as factors. In order to explore if there were significant changes in soil organic $\mathrm{C}$, total $\mathrm{N}$, extractable $\mathrm{K}$, and CEC from pre-treatment $(\mathrm{T}=0)$ and post-treatment ( $\mathrm{T}=2 \mathrm{yrs}$.), we employed a three-way repeated measures ANOVA with treatment, site, and year as factors for the model and interactions. Soil moisture and temperature were analyzed using a two-way repeated measures ANOVA with treatment and orchard as factors.

Statistical tests were performed using RStudio 3.3.1. All analyses were tested for normality using the Shapiro-Wilk test. Heteroscedasticity was analyzed by plotting residuals on a qq-plot. Variables that were not normally distributed were $\log$ transformed $\left(\log _{10}\right)$ to meet assumptions for ANOVA. Arithmetic means are shown in tables and figures. Statistical significance was established a prior at $\alpha=0.05$.

\section{Results}

OMA initial nutrient composition, decomposition, and nutrient dynamics

Initial OMAs nutrient composition was different between years for some elements (Table 1). The MWC in 2016 and 2017 had 60\% higher total C concentrations $(p<0.001)$ and $64 \%$ higher $\mathrm{C}: \mathrm{N}$ ratio $(p<0.001)$, and lower concentrations of $\mathrm{P}(61 \%$; $p<0.001), \mathrm{S}(24 \% ; p<0.001), \mathrm{Ca}(19 \% ; p=0.007)$, $\mathrm{Mg}(8 \% ; p=0.040), \mathrm{Cu}(35 \% ; p<0.001), \operatorname{Mn}(31 \%$; $p<0.001)$, and Zn $(22 \%$; $p=0.004)$ in 2016 compared to 2017. However, initial concentrations of $\mathrm{N}$ $(p=0.954), \mathrm{K}(p=0.906), \mathrm{Fe}(p=0.782)$, and $\mathrm{B}$ $(p=0.173)$ were similar between years within an 

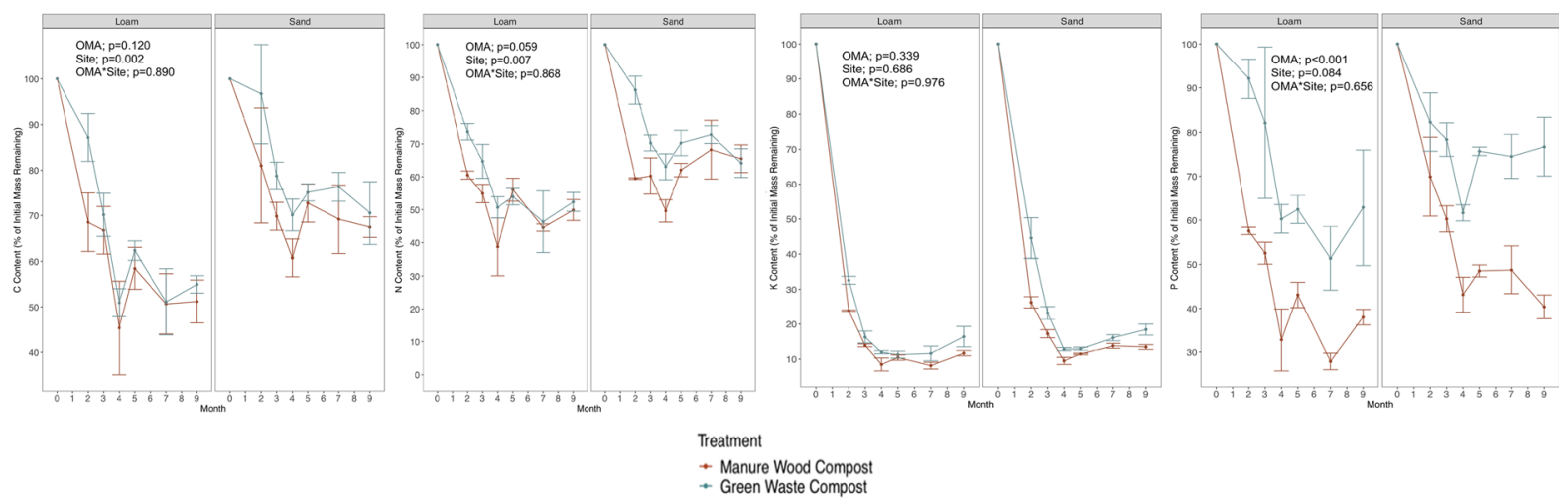

Fig. 1 Effect of different OMAs application and soil texture on soil (0-0.1 m) a organic carbon (C), b total nitrogen $(\mathrm{N})$, $\mathbf{c}$ total phosphorus $(\mathrm{P})$, and $\mathbf{d}$ total potassium $(\mathrm{K})$ remaining in Organic Matter Amendments (OMAs) during decomposition in two

OMA type. The initial nutrient concentrations of $\mathrm{K}$ $(10 \% ; p=0.009), \mathrm{S}(10 \% ; p=0.033), \mathrm{B}(10 \%$; $p=0.020)$, and $\mathrm{Cu}(15 \% ; p<0.001)$ in the GWC OMA were higher in 2016 than in 2017. However, the initial nutrient concentrations of $\mathrm{C}(p=0.831), \mathrm{N}$ $(p=0.792), \mathrm{C}: \mathrm{N}$ ratio $(p=0.415), \mathrm{P}(p=0.944), \mathrm{Ca}$ $(p=0.897), \mathrm{Fe}(p=0.849), \mathrm{Mg}(p=0.614), \mathrm{Mn}$ $(p=0.169)$, and $\mathrm{Zn}(p=0.900)$ in the GWC were similar between years.

We found that net loss of $\mathrm{C}(p=0.120), \mathrm{N}$ $(p=0.059)$, and $\mathrm{P}(p<0.001)$ was generally faster for MWC than GWC, but only net $\mathrm{P}$ release was statistically significant (Fig. 1). Net nutrient loss of these same nutrients was also significantly influenced by site, with net release generally faster in the Loam than the Sand site $(\mathrm{C}, p=0.002 ; \mathrm{N}, p=0.007$; and $\mathrm{P}$, $p=0.084)$. Net $\mathrm{K}$ release during OMA decomposition was not influenced by OMA type ( $p=0.339)$ or by site ( $p=0.686$; Fig. 2d). For all four nutrients, we found no significant interaction between OMA type and site $(p>0.640)$.

\section{Soil moisture response to OMA}

There were significant treatment $(p<0.001)$ and site $(p<0.001)$ effects on soil moisture $(0-0.1 \mathrm{~m}$ depth), with no significant interaction between these two factors ( $p=0.340$; two-way repeated measures ANOVA). A two-way repeated measures ANOVA model for the Loam site showed soils amended with MWC $(p<0.001)$ and GWC $(p<0.001)$ had a $29 \%$ almond orchards. Statistics describe a two-way repeated measures ANOVA $(p<0.05)$. Error bars denote \pm one standard error of the mean

and $29 \%$ higher soil moisture content than the control, respectively. No interaction was observed between treatment and month ( $p=0.872)$. No differences were observed between both OMA at the Loam site ( $p=0.872$; Fig. 2). At the Sand site, soils amended with both MWC (28\%) and GWC (37\%) had higher soil moisture content than the unamended control soils (both $p<0.001$ ). There was no interaction between treatment and month $(p=0.466)$. Soil moisture content did not differ significantly between the two OMAs ( $p=0.748)$. Soil temperature $(0.1 \mathrm{~m}$ depth) was not significantly influenced by OMAs $(p=0.321)$ or soil type ( $p=0.210$; data not shown; Loam site $=16.7 \pm$ $0.1{ }^{\circ} \mathrm{C}$; Sand site $=16.6 \pm 0.1{ }^{\circ} \mathrm{C}$ ).

Soil inorganic $\mathrm{N}$ response to OMA

A two-way repeated measures ANOVA was performed with treatment and site as factor showed no significant difference in soil $\mathrm{NH}_{4}^{+}$concentrations $(0-0.1 \mathrm{~m})$ among treatments during the two-year experiment $(p=0.480)$. No site $(p=0.092)$ or treatment by site interactions were observed $(p=0.870)$.

The application of OMAs significantly increased $\mathrm{NO}_{3}{ }^{-}$concentrations $(0-0.1 \mathrm{~m})$ in amended soils $(p<0.001)$. Concentrations of $\mathrm{NO}_{3}{ }^{-}$were significantly different between the control and the MWC $(p=0.028)$ and the GWC $(p=0.004)$ treatments. There were also differences observed between the Loam and Sand site $(p<0.001)$. No interactions were found between sites and treatments $(p=0.745)$. 


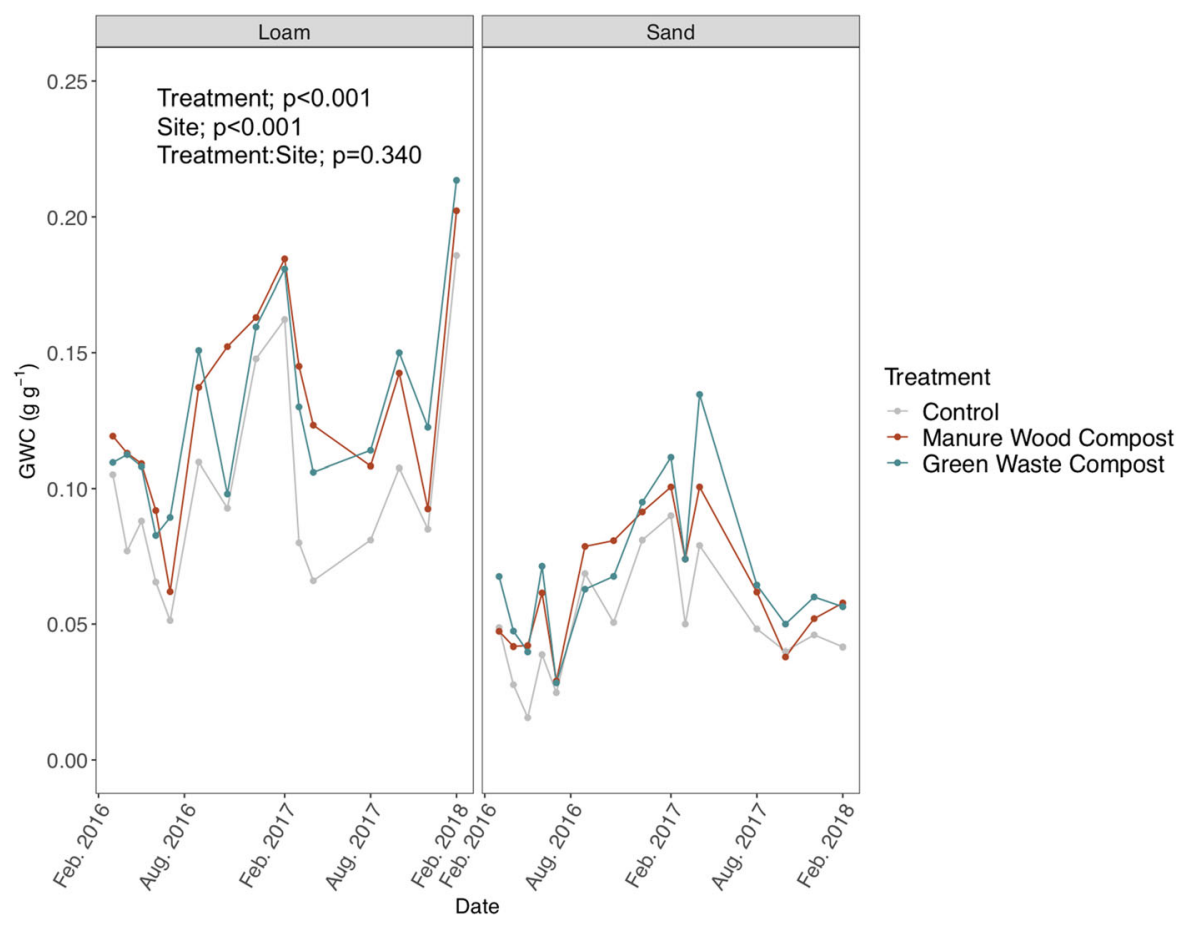

Fig. 2 Soil moisture $(0-0.1 \mathrm{~m})$ during the two-year study period. Symbols denote means and error bars are standard errors of the mean $(n=3-4)$. A two-way repeated measures ANOVA was performed $(p<0.05)$

Total inorganic $\mathrm{N}$ concentrations were significantly different between the control and MWC $(p=0.025)$ and GWC ( $p=0.004$; Fig. 3). No differences were observed between the OMA types $(p=0.710)$ and no interactions were observed between treatment and site $(p=0.763)$. We also found total inorganic $\mathrm{N}$ concentrations differed between the Loam and Sand sites over the two-year study (both $p<0.001$ ). A two-way repeated measures ANOVA showed no significant differences in total inorganic $\mathrm{N}$ concentration among the treatments in the Loam site $(p=0.216)$. However, differences were observed among months $(p=0.005)$, with no interactions between month and treatment $(p=0.909)$. A two-way repeated measures ANOVA showed significant treatment differences $(p=0.001)$ in total inorganic $\mathrm{N}$ concentrations between the control and both MWC $(p=0.042)$ and GWC $(p=0.012)$ treatments at the Sand site. Both OMAs were not significantly different from each other in total inorganic $\mathrm{N}$ concentrations $(p=0.771)$. Total inorganic $\mathrm{N}$ concentrations were different among months at the Sand site $(p=0.016)$.
Available $\mathrm{N}$ and $\mathrm{P}$ measured by IER

Inorganic $\mathrm{N}$ fluxes measured by ion exchange resins were not significantly different among treatments $(p=0.518)$. However, inorganic $\mathrm{N}$ concentrations from IER showed differences between sites $(p<0.001)$ and year $(p=0.046)$. There was no interaction between treatment and year $(p=0.713)$, treatment and site $(p=0.640)$, and treatment, site, and year $(p=0.667$; Fig. 4a.). A similar three-way repeated measures ANOVA model was used to determine differences between resin $\mathrm{P}$ concentrations. There were significant treatment ( $p=0.036$; Fig. $4 \mathrm{~b}$.) and site differences $(p<0.001)$. However, there was no difference between years ( $p=0.648)$. A marginally significant interaction between treatment and year occurred $(p=0.067)$. No interaction was observed between treatment and site $(p=0.245)$, and treatment, year, and site $(p=0.961)$.

Soil organic $\mathrm{C}$ and total $\mathrm{N}$

Soil organic $\mathrm{C}$ and total $\mathrm{N}$ concentrations $(0-0.1 \mathrm{~m})$ were analyzed prior to OMA application in 2016 and 


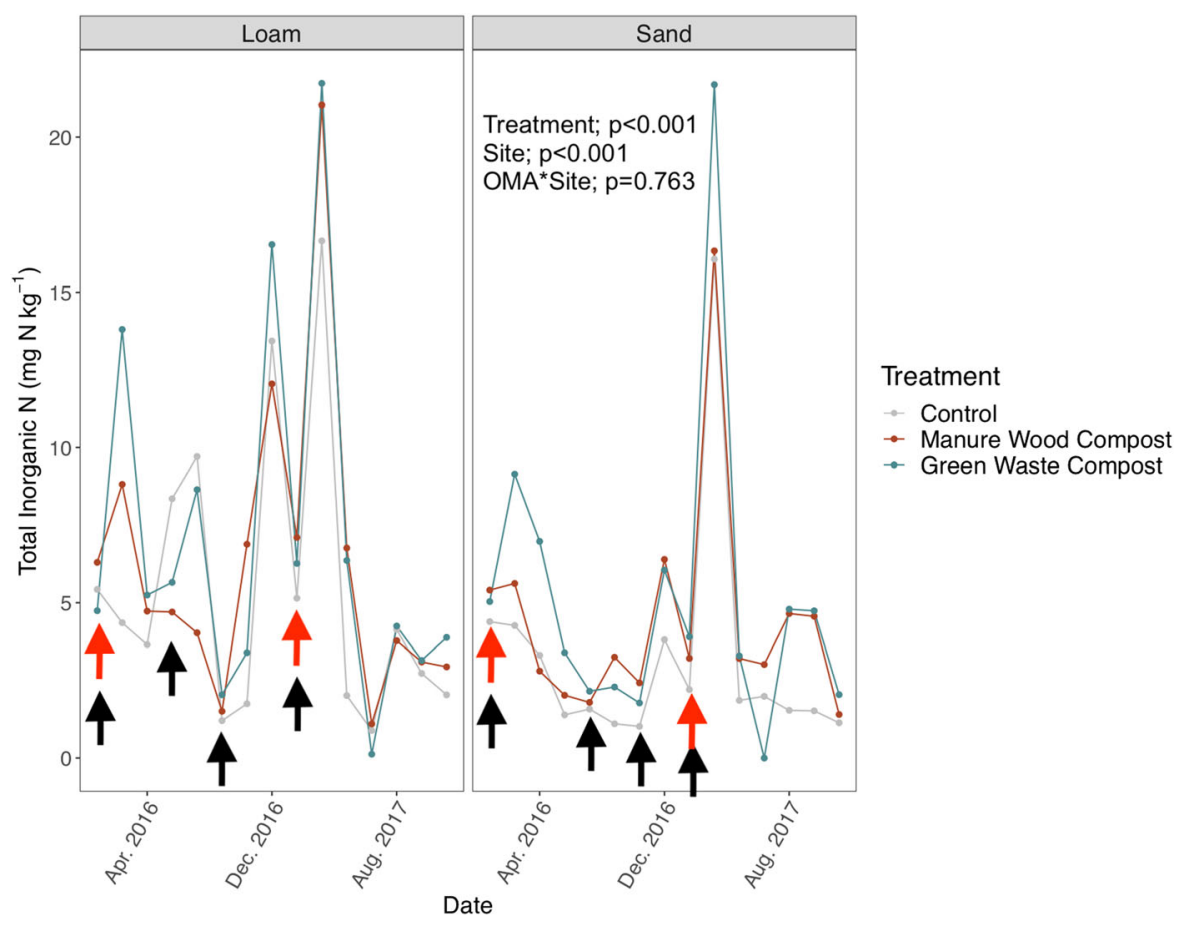

Fig. 3 Soil (0-0.1 m) inorganic nitrogen $(\mathrm{N})$ dynamics during the two-year study period. Symbols denote means and error bars are standard errors of the mean $(n=3-4)$. The red arrows denote the timing of the application of the OMAs and the black

at the end of the study (2018). Results from the threeway repeated measures ANOVA showed treatment $(p<0.001)$, site $(p<0.001)$, and year $(p=0.004)$ effects on soil organic $\mathrm{C}$, with a significant treatment by year interaction $(p=0.002)$. No significant interactions were observed between: treatment and site $(p=0.306)$; site and year $(p=0.411)$; and treatment, site, and year $(p=0.912)$. A Tukey's post hoc test shows soil organic C concentration significantly increased from pre- (2016) and post- (2018) application in both the MWC $(p=0.006)$ and GWC ( $p=0.006)$ treatments, but no change was observed in the control $(p=0.707)$. The MWC treatment increased soil organic $\mathrm{C}$ by $33 \%$ in the Loam site and by $50 \%$ in the Sand site after two years of OMA application (Fig. 5a). The GWC treatment increased soil organic C by $92 \%$ in the Loam site and $67 \%$ in the Sand site. Significant treatment, site, and year main effects occurred for soil total $\mathrm{N}$ concentration (all $p<0.001)$. A significant treatment by year interaction also occurred $(p=0.002)$. There were no significant interactions observed between: treatment and site $(p=0.313)$; site and year $(p=0.439)$; and treatment, arrows denote the timing of fertilization events (see Materials and Methods). A two-way repeated measures ANOVA was performed $(p<0.05)$. Error bars denote \pm one standard error of the mean

site, and year $(p=0.914)$. A Tukey's post hoc test showed both the MWC $(p=0.020)$ and the GWC $(p=0.001)$ treatments increased soil total $\mathrm{N}$ concentrations from pre- and post- applications (i.e., after two years), while the control ( $p=0.970)$ did not change (Fig. 5b). Soil total $\mathrm{N}$ concentration increased in the MWC treatment by $36 \%$ in the Loam site and by $80 \%$ in the Sand site after two years of OMA applications. Soil total $\mathrm{N}$ concentration in the GWC treatment increased by $75 \%$ in the Loam site and by $100 \%$ at the Sand site from 2018 to 2019.

\section{Soil $\mathrm{K}$ availability and CEC}

Results showed K availability (as measured by extractable $\mathrm{K}$ in top $0.1 \mathrm{~m}$ soil) was significantly different among treatments, and between sites and years (all $p<0.001$ ), with a significant site by year interaction ( $p=0.004$; Fig. $6 \mathrm{~b}$ ). No significant interactions were observed: between treatment and site $(p=0.825)$; treatment and year $(p=0.174)$; or treatment, site, and year $(p=0.102)$. Soil available $\mathrm{K}$ in MWC plots increased by $14 \%$ in the Loam site and by 

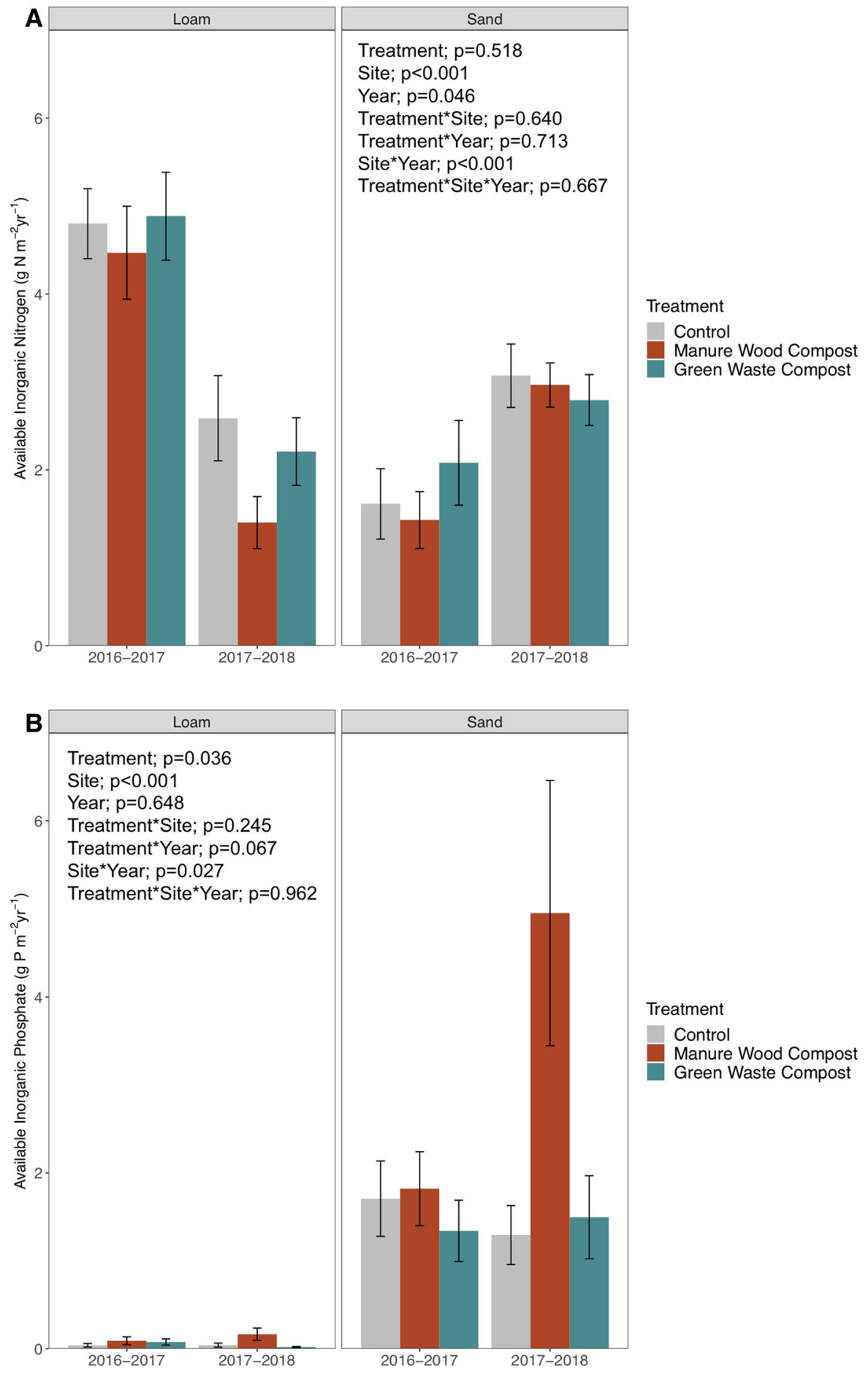

Fig. 4 Mean inorganic nitrogen (N) and phosphorus (P) fluxes (over a two-year period) determined by adsorption on ion exchange resin bags placed at a $0.5-\mathrm{m}$ mineral soil depth in the absence of plant nutrient uptake. A three-way repeated measures ANOVA was used $(p<0.05)$. Colored bars denote mean values and error bars denote \pm one standard error of the mean $(n=8)$ 

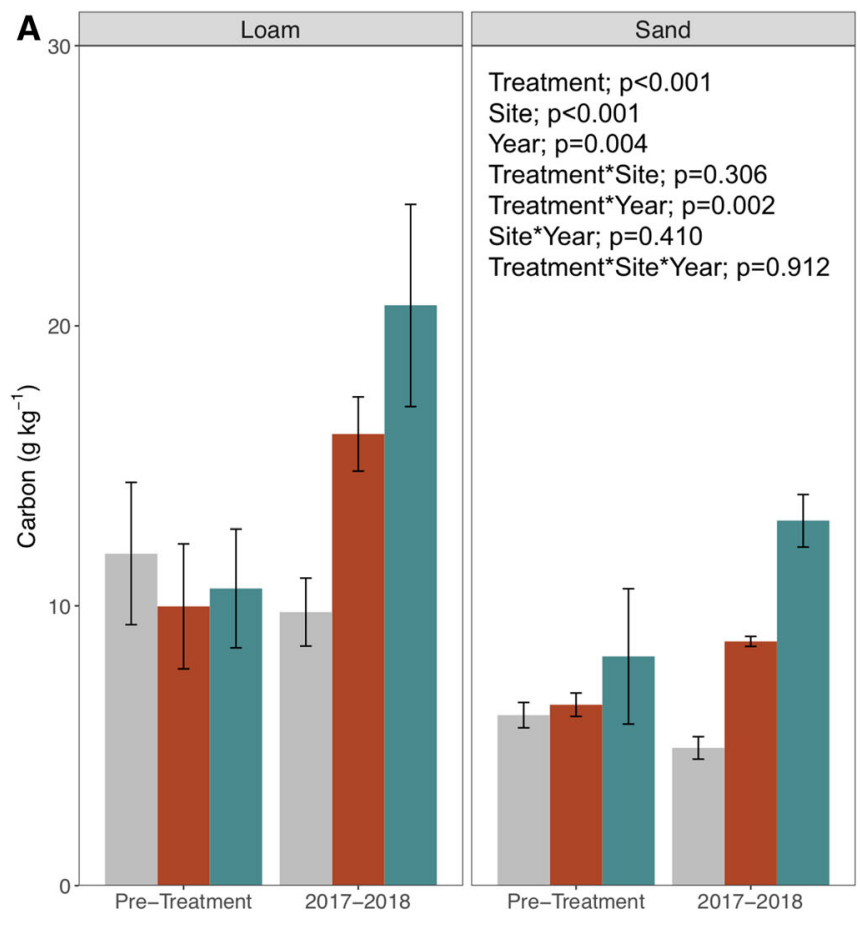

\section{Treatment \\ Control \\ Manure Wood Compost \\ Green Waste Compost}
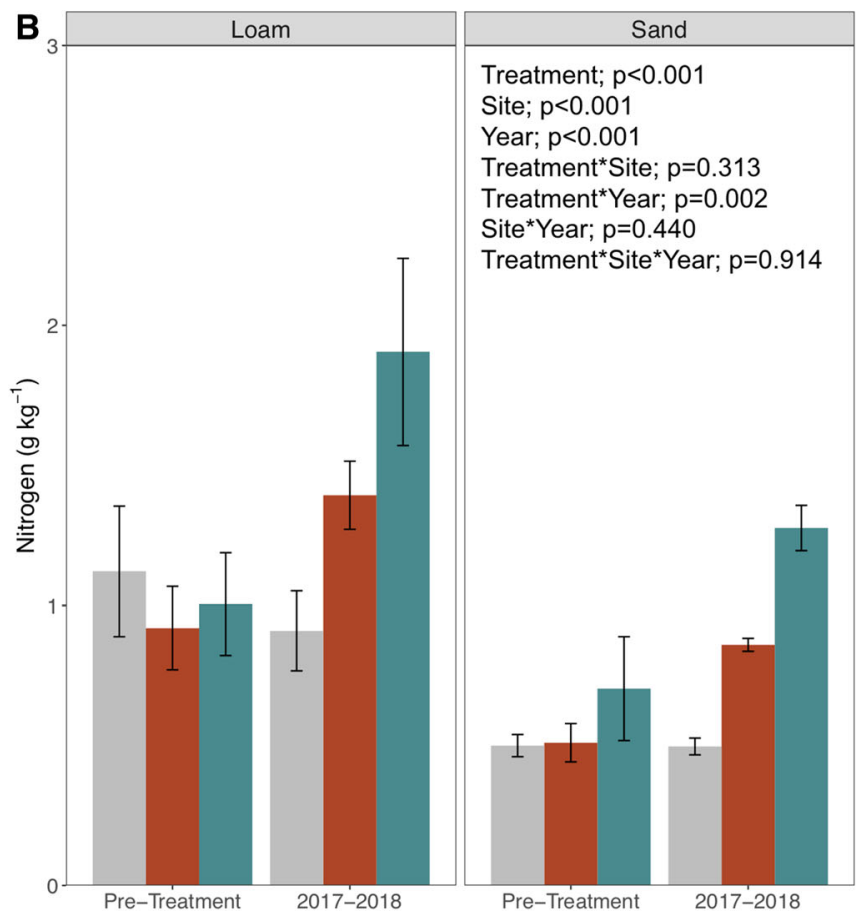

Treatment

Control

Manure Wood Compost

Green Waste Compost

Fig. 5 Soil $(0-0.1 \mathrm{~m})$ organic carbon (a) and total nitrogen (b) before (2016) and after (2018) two years of application of two different organic matter amendments to almond orchards of contrasting soil texture. A three-way repeated measures
ANOVA was used $(p<0.05)$. Colored bars denote mean values and error bars denote \pm one standard error of the mean $(\mathrm{n}=3-4)$ 

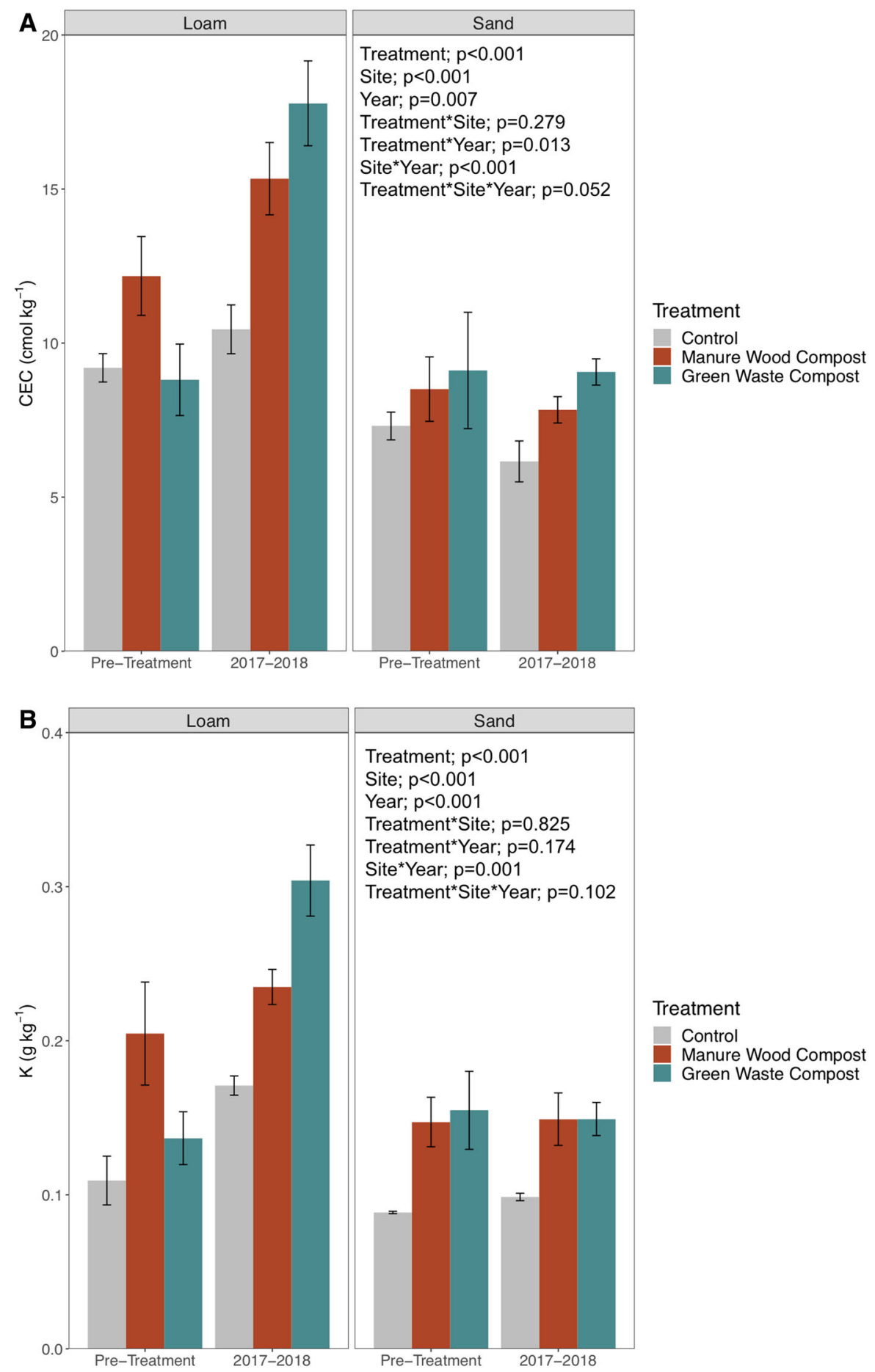

Treatment

Control

Manure Wood Compost

Green Waste Compost

Fig. 6 a Changes in soil (0-0.1 mm) cation exchange capacity (CEC) and b potassium (K) before (2016) and after (2018) two years of application of two different organic matter amendments to almond orchards of contrasting soil texture. A three-way repeated measures ANOVA was used $(p<0.05)$. Colored bars denote mean values and error bars denote \pm one standard error of the mean $(n=3-4)$ 
$9 \%$ in the Sand site. A Tukey's post hoc showed that the MWC $(p<0.001)$ and GWC $(p<0.001)$ were significantly higher than the control, but both amendments were not significantly different from each other $(p=0.950)$. The GWC treatment contributed to a $138 \%$ increase in available $\mathrm{K}$ in the Loam site and a $7 \%$ decrease in the Sand site. The controls increased by $45 \%$ in the Loam site and by $11 \%$ in the Sand site.

Soils (0-0.1 m depth) collected from both sites before treatment and after two years of OMA application showed significant increases in CEC. Threeway repeated measures ANOVA showed significant treatment $(p<0.001)$, site $(p<0.001)$, and year $(p=0.007)$ effects (Fig. 6a). An interaction occurred between treatment and year $(p=0.001)$, showing differences in soil CEC between control and MWC $(p=0.045)$ and GWC $(p<0.001)$ in 2018. There was a marginally significant three-way interaction among treatment, site, and year $(p=0.052)$, and no significant interaction between treatment and site occurred $(p=0.279)$. Tukey's post-hoc test showed that the GWC treatment significantly increased in CEC from pre-application to post-application $(p<0.001)$, but the MWC treatment did not significantly increase CEC $(p=0.780)$. The CEC in the control remained similar after two years $(p=1.000)$. Soil CEC increased by $29 \%$ and $14 \%$ after two years of OMAs from pre- and post- application in the Loam and Sand sites, respectively. The greatest relative change in soil CEC occurred with the GWC treatment, where the soil CEC increased by $90 \%$ in the Loam site and by $25 \%$ in the Sand site (Fig. 6).

\section{Discussion}

Our study shows that the application of OMAs improves soil fertility $(0-0.1 \mathrm{~m})$ through the enhancement of soil water content, CEC, and total $\mathrm{C}$ and $\mathrm{N}$. Although, increases in inorganic $\mathrm{N}$ were short-lived, continued application of OMAs may lead to more sustained increases in inorganic N. Moreover, the effect of OMAs on orchard soils depended on the soil type, suggesting that soil texture (and potentially other unmeasured soil properties) modulates the soil fertility response to OMAs. Results of this study demonstrated that application of OMAs can positively influence soil chemical properties and soil water dynamics of orchard soils in the short-term.
OMA decomposition rates and net nutrient release

Decomposition of organic matter represents the primary source of nutrients for plants, and nutrients and energy for soil microbes in unfertilized fields. We hypothesized that the decomposition rate (i.e., net decrease in C) and net nutrient release from the GWC would be higher than from the MWC because of the lower initial C:N mass ratio of the former OMA in the 2016 amendments (Table 1). However, in contrast to our hypothesis, we generally found faster decomposition and net release of $\mathrm{N}$ and $\mathrm{P}$ from the MWC amendment than from the GWC amendment. Faster decomposition and net $\mathrm{N}$ and $\mathrm{P}$ release from the higher initial $\mathrm{C}: \mathrm{N}$ ratio amendment could be due to the finer particle size of the MWC than the GWC amendment, which would result in both greater surface area for microbial colonization in the MWC and greater ease of movement of this material out of our decomposition rings and into the mineral soil (Ozores-Hampton et al. 2011). Alternatively, these differences in decomposition rate and net $\mathrm{N}$ and $\mathrm{P}$ release may also be due to unmeasured differences in the water-soluble components between the two amendments, with higher soluble fractions in the MWC than the GWC (Dey et al. 2019).

Interestingly, even though the OMAs were applied to the soil surface and not incorporated into the mineral soil, the decomposition rate and net $\mathrm{N}$ and $\mathrm{P}$ release was higher in the loam site than the sand site. Because soil temperatures and exogenous water and inorganic nutrient inputs were similar between sites, this result suggesting that the underlying mineral soil texture influenced these nutrient cycling processes (Forte et al. 2017). Higher rates in the loam site could be the result of greater underlying soil moisture in the loam site than in the Sand site, increasing the availability of water to microbial decomposers in the OMAs. Capillary fringe movement of water from the mineral soil to the overlying OMAs would be expected to be greater in the loam than the Sand site soil (Weil and Brady 2017).

As has been observed in other decomposition studies using fresh plant litter (Harmon et al. 2009; Hart et al. 1992) or composted organic matter (Bar-Tal et al. 2004; Wang et al. 2015), net release of $\mathrm{K}$ from the OMAs in this study was much faster than $\mathrm{C}, \mathrm{N}$ or $\mathrm{P}$ loss, suggesting that $\mathrm{K}$ release is governed primarily by physical rather than biological processes (Bar-Tal 
et al. 2004). Similarly, a study focusing on OMA application in almond orchards by Khalsa and collaborators (unpublished data) found that $\mathrm{K}$ nutrient release was more rapid than $\mathrm{C}, \mathrm{N}$, and $\mathrm{P}$. In support of this hypothesis is our finding that OMA type had no significant effect on net $\mathrm{K}$ release despite the higher initial K concentration of MWC than GWC (Table 1). Additionally, unlike the more microbial-influenced nutrients $\mathrm{N}$ and $\mathrm{P}$ where site was a significant factor, net $\mathrm{K}$ release was unaffected by site. Taken together, these results support other OMA decomposition studies that demonstrate that, unlike fresh plant litter, decomposition and net nutrient release from OMAs are not strongly regulated by their initial chemical composition (Ryals and Silver 2013).

\section{OMA increases moisture content in soils}

One potential benefit of using OMAs is to increase the capacity of the soil to retain rain and irrigation water as soil moisture (Martínez-Blanco et al. 2013). The ability for soil to hold onto water is an important factor that controls plant growth, influences plant $\mathrm{C}$ allocation, nutrient cycling and rate of photosynthesis (Lepsch et al. 2019; Minasny and McBratney 2018). Some studies have shown that the application of OMAs can improve soil aggregate stability, porosity, and infiltration and water-holding capacity, and plant water status (Karami et al. 2012; Liu and Zhou 2017). The Sand site had an increase of $28 \%$ in soil moisture content (0-0.1 m mineral soil depth) in MWC amended soils and a $37 \%$ increase from the GWC amended soils. Whereas, soil moisture increased significantly by $28 \%$ in the MWC treatment and $27 \%$ in the GWC treatment at the Loam site. The application of the OMAs in the Sand site likely increased plant available water storage by increasing water content of the soil at field capacity (Karami et al. 2012).

Plant available nutrients

\section{Soil inorganic $N$}

Monthly soil sampling from 0 to $0.1 \mathrm{~m}$ showed that a fertigation event occurred around the same time as the application of OMAs, possibly contributing to the momentary spike in inorganic $\mathrm{N}$ in both years (Fig. 4). Soil inorganic $\mathrm{N}$ concentrations in OMA soils increased tenfold relative to the unamended controls after application, followed by a rapid decrease to preapplication levels after one month. Fertilization was shown to have increased inorganic $\mathrm{N}$ three times as much from pre-fertilization levels in the control soils at both sites.

Our results showing immediate but short-term increases in soil inorganic $\mathrm{N}$ pools following OMA additions is consistent with some previous OMA studies (Blackshaw et al. 2005; Eghball 2002). Longer-term applications of compost (i.e., $>4-5$ years) may be required before sustained increases in soil total inorganic $\mathrm{N}$ are observed (Blackshaw et al. 2005; Eghball 2002). How long OMAs need to be applied to soil in order to achieve an elevated and sustained increase in plant available $\mathrm{N}$ depends on many factors such as climate, soil type, management systems, compost type, and application rates.

In a four year study focusing on annual fertilization rates $\left(140,224,309\right.$ and $\left.392 \mathrm{~kg} \mathrm{ha}^{-1} \mathrm{~N} \mathrm{yr}^{-1}\right)$ in mature 'Nonpareil' almond orchards in Kern County California, maximum yield was observed at the $309 \mathrm{~kg} \mathrm{~N} \mathrm{ha}^{-1}$ rate (Muhammad et al. 2018). The highest application rate of $392 \mathrm{~kg} \mathrm{~N} \mathrm{ha}^{-1}$ did not increase fruit, leaf or perennial tissue $\mathrm{N}$ suggesting that "excess" $\mathrm{N}$ was not used by trees. At the same time, the $309 \mathrm{~kg} \mathrm{~N}^{-1}$ rate significantly increased soil organic $\mathrm{C}$ and total $\mathrm{N}$ compared to the lower rate of $224 \mathrm{~kg} \mathrm{~N} \mathrm{yr}^{-1}$ (Khalsa et al. 2020). Intensive $\mathrm{N}$ use in almond orchards can lead to both productivity and agricultural sustainability goals. Continuing application of OMA can provide substantial $\mathrm{N}$ for almond productivity that can lead to lower dependence on $\mathrm{N}$ fertilizer use while improving overall soil fertility and soil C storage.

\section{Available $N$ and $P$ measured by IER}

We found no significant increase in plant-available $\mathrm{N}$ following OMA applications using ion exchange resins (IER) placed at a $0.5 \mathrm{~m}$ soil depth. Nevertheless, IER did suggest higher $\mathrm{N}$ availability in the Loam than the Sand Site. This result is consistent with the higher soil total $\mathrm{N}$ concentration found in soils from the Loam site (Fig. 6b). In contrast, available P measured using this same method showed that the MWC, but not the GWC, treatment increased plant-available $P$ after the second application. This result may be due to the very high initial $\mathrm{P}$ concentration in the MWC amendments 
used in the second year (2017; Table 1). These results suggest that certain OMA that are high in initial P may substantially increase plant available $\mathrm{P}$ in the plant rooting zone even when these materials are applied to the surface as in orchards. Furthermore, in contrast to the higher available $\mathrm{N}$ in the Loam site measured using IER, available $\mathrm{P}$ was substantially higher in the Sand site than the Loam site.

Our IER nutrient values were influenced by environmental and experimental factors (Binkley and Hart 1989; Tahovská et al. 2018, 2010). The $0.5 \mathrm{~m}$ PVC pipe excluded plant uptake, allowing nutrients to leach to the bottom where the IER was located. Greater water transport is expected in the Sand site due to coarser soil texture versus the Loam site, facilitating nutrient transport. Differences between plant-available $\mathrm{N}$ and $\mathrm{P}$ concentrations from the IER were shown to be possibly attributed to $\mathrm{N}$ in OMA still in the organic state. It is uncommon for deciduous tree crops to be $\mathrm{P}$ deficient in California (Carlson 1996; Warren 1996); therefore, there is no reason for growers to apply additional $\mathrm{P}$ fertilizer to orchards unless to provide for the P-demands of a cover crop (Carlson 1996).

\section{Available $\mathrm{K}$}

The application of OMA contributed to increases in soil K availability. Previously, yard waste composts have been shown to increase soil available $\mathrm{K}$ because of the large proportion of woody plant material (Hartl et al. 2003; Parkinson et al. 1996). For instance, Parkinson et al. (1996) found that incorporation of 15, 30 , and $50 \mathrm{tha}^{-1}$ of yard waste compost applied three times over twenty years increased soil available $\mathrm{K}$ by $40 \%, 60 \%$, and $184 \%$ respectively. The application of manure amendments has also shown to increase available soil K. In a three-year experiment in apple orchards in Washington State, USA, researchers found that a dairy compost, at an application rate of $50 \mathrm{t}$ $\mathrm{ha}^{-1}$, increased available $\mathrm{K}$ by $185 \%$ (Forge et al. 2013). We found no differences between OMA type contributing to K availability, but both the MWC and GWC contributing to significant increases relative to the control.

Plants require large amounts of $\mathrm{K}$, but the mobility of $\mathrm{K}$ in soils is relatively low (Carlson 1996). Hence, one major challenge is applying sufficient amount of $\mathrm{K}$ to obtain crop responses in finer textured soils. Sandy soils do not have the capacity to bind $\mathrm{K}$ due to fewer exchange sites; consequently, leading to higher applications of fertilizer or OMA (Carlson 1996). In a study focusing on fertilizer rates in almond orchards, Muhammad et al. (2018) concluded that almond orchard soils that had a baseline of $100-150 \mathrm{mg} \mathrm{kg}^{-1}$ of soil exchangeable $\mathrm{K}$ would need only an application $112 \mathrm{~kg} \mathrm{ha}^{-1}$ with any fertilizer source to satisfy plant $\mathrm{K}$ demand. Soil exchangeable K pre-compost application in our study were $170 \mathrm{mg} \mathrm{kg}^{-1}$ at the Loam site and $100 \mathrm{mg} \mathrm{kg}^{-1}$ at the Sand site (Fig. 6.). After the experiment MWC amended soils were $240 \mathrm{mg} \mathrm{kg}^{-1}$ and $150 \mathrm{mg} \mathrm{kg}^{-1}$ in the Loam and Sand sites, respectively. The GWC amendment increased exchangeable $\mathrm{K}$ to $310 \mathrm{mg} \mathrm{kg}^{-1}$ in the Loam site and $150 \mathrm{mg} \mathrm{kg}^{-1}$ in the Sand site. Approximately a total of $4304 \mathrm{~kg} \mathrm{~K} \mathrm{ha}^{-1}$ were applied in 2016 and a total of $3228 \mathrm{~kg} \mathrm{~K} \mathrm{ha}^{-1}$ were applied in 2017 . These calculations suggest that the application of OMA supplied sufficient amount of $\mathrm{K}$ for both orchards, which would allow the reduction of $\mathrm{K}$ fertilizer at these two sites.

\section{OMA effects on CEC}

We expected that the Sand site would exhibit the greatest increase in soil CEC because of the lower soil CEC in the unamended coarser textured soil (Fig. 6). In contrast to our hypothesis, we found substantial increases in soil CEC after just two years of OMA applications applied to the ground surface but only in the finer textured soil (Loam site). As noted above, application of OMAs has been shown to increase organic C stocks, which often correlates with an increase in CEC in soils (Diacono and Montemurro 2010). This correlation is due to the high abundance of negatively charged sites found in organic matter, especially at higher pH (Garcia-Gil et al. 2004; Kaur et al. 2008). We also found greater increases in soil organic C in the Loam site than the Sand site, suggesting that this increase in soil CEC was driven by increases in SOM (see below).

We speculate that significant increases in soil CEC only occurred in the Loam site because the Sand site did not have enough charged surfaces (e.g., clay) to sorb the OMA-derived new soil organic matter. The higher abundance of charged surfaces in the Loam site soil protected more of the OMA-derived soil organic matter from decomposition and leaching (Garcia-Gil 
et al. 2004; Kaur et al. 2008). Soils that have higher CEC have a greater capacity to store plant available nutrients, whether derived from added OMAs or from other sources (Garcia-Gil et al. 2004). How long-lived these increases in CEC likely depend on the capacity of soil to physically protect these SOM pools from decomposition and leaching (Diacono and Montemurro 2010). Coarser textured soils are in greater need of increases in CEC from OMA-derived organic matter because of their low clay concentrations and relatively high rates of nutrient loss from leaching (Ozores-Hampton et al. 2011). More frequent and higher application rates may be needed to provide equivalent effects of soil CEC for coarser textured soils.

\section{Soil organic C and total $N$}

Organic matter amendments that decomposed faster resulted in greater increases in surficial $(0-0.1 \mathrm{~m})$ soil $\mathrm{C}$ and $\mathrm{N}$ pools. The faster and greater loss of $\mathrm{C}$ and $\mathrm{N}$ from the GWC amendment than the MWC amendment resulted in a greater increase in soil total $\mathrm{C}$ and $\mathrm{N}$ pools, yet both OMAs increased soil $\mathrm{C}$ and $\mathrm{N}$ pools over unamended control soils. We found that soil collected from 0 to $0.1 \mathrm{~m}$ increased in soil $\mathrm{C}$ and $\mathrm{N}$ after two years of OMA application. Soil organic C and total $\mathrm{N}$ increased in soils at both sites. Soil $\mathrm{C}$ concentrations increased by an average of $70 \%$ and total $\mathrm{N}$ by an average of $90 \%$ in the OMA plots relative to controls. These increases in soil organic $\mathrm{C}$ in the OMA plot may play an essential role in the nutrient content and availability ( $\mathrm{Li}$ et al. 2017; Liu and Zhou 2017; Zhao et al. 2009).

We found in our study the impact of OMA additions contributed to increases in organic $\mathrm{C}$ and total $\mathrm{N}$ in only 2 years with typical agronomic OMA application rates. Longer and higher rates of OMA application may continue to contribute to organic $\mathrm{C}$ and $\mathrm{N}$ pools. In a fourteen-year nectarine orchard study conducted in Italy, Baldi et al. (2018) found that two application rates $\left(5 \mathrm{Mg}\right.$ dry weight of compost (DW) $\mathrm{ha}^{-1} \mathrm{yr}^{-1}$ and $10 \mathrm{Mg} \mathrm{DW} \mathrm{ha} \mathrm{yr}^{-1}$ ) increases organic $\mathrm{C}$ concentrations in the top $0.65 \mathrm{~m}$ of soil. The highest application rate contributed to $60 \%$ of $\mathrm{C}$ sequestration from the amendment source over fourteen years. Some studies, such as in Glover et al. (2000), reported no changes in SOC stocks in the top $0.15 \mathrm{~m}$ after 4 years of application of poultry manure and bark mulch in apple orchards. It was concluded that the high initial C levels and historical land use as a dairy farm decreased decomposition rates, resulting in these OMAs contributing little to SOC pools (Powlson and Jenkinson 1981). In contrast, Mbau et al. (2015) found an increase soil organic $\mathrm{C}$ and total $\mathrm{N}$ in the top $0.2 \mathrm{~m}$ of soil after 17 months from the application of six different composts at a rate of $5 \mathrm{Mg} \mathrm{ha}^{-1}$ in nutrient deficient maize field soils. The differences among these studies are most likely due to the chemical composition of the OMA used in the study, the rate of application, the length of the study, or sampling depth.

\section{Conclusion}

Our results have important implications for managing agricultural soils, particularly permanent crops in California's Central Valley. Our study demonstrates that composts derived from readily available dairy cow manure and green yard waste can significantly improve soil fertility after one or two annual applications, and that fertility gains appear to be more dependent on soil texture than the nutrient concentrations of the OMA. By improving soil fertility, OMAs have the potential to provide co-benefits to growers, such as sustaining the productivity of their soils, reducing inorganic fertilizer usage, recycling on site, and increasing yields.

Soil fertility is the ability of soil to sustain agricultural plant growth, resulting in sustained and consistent high-quality yields. The continuation of this study to tree maturity would allow the evaluation of the impact of these OMAs on crop yields and quality. Although we found soil nutrient and water content differences resulting from OMAs at two sites with differing textures, we recognize that this study did not evaluate other physical and biological components of soil fertility. Multiyear field studies are needed to explore long-term benefits of OMAs in orchard systems with different environmental variables in order to fully assess OMA influences on long-term soil fertility and crop yield.

Acknowledgements We thank M. Barnes, M. Castro, D. Davenport, N. Dove, O. Elias, S. Glasser, and J. Wu for their assistance in supporting this research. We also thank the farming partners who made it possible to conduct this research in their orchards. Finally, we thank the Almond Board of California, the CDFA Specialty Crop Block Grant Program under agreement 
SCB15033, and USDA Hispanic Serving Institutions for their financial support.

Funding Almond Board of California, the CDFA Specialty Crop Block Grant Program under agreement SCB15033, and USDA Hispanic Serving Institutions.

Availability of data and material Will provide upon request.

\section{Declarations}

Conflict of interest The authors declared that they have no conflict of interest.

Open Access This article is licensed under a Creative Commons Attribution 4.0 International License, which permits use, sharing, adaptation, distribution and reproduction in any medium or format, as long as you give appropriate credit to the original author(s) and the source, provide a link to the Creative Commons licence, and indicate if changes were made. The images or other third party material in this article are included in the article's Creative Commons licence, unless indicated otherwise in a credit line to the material. If material is not included in the article's Creative Commons licence and your intended use is not permitted by statutory regulation or exceeds the permitted use, you will need to obtain permission directly from the copyright holder. To view a copy of this licence, visit http://creativecommons.org/licenses/by/4.0/.

\section{References}

Acatrinei O, Buftia G, Lazăr I-M, Rusu L (2019) Aerobic composting of mixing sewage sludge with green waste from lawn grass. Environ Eng Manag J 18(8):1789-1798

Almond Almanac (2018) Almond Board of California. https:// www.almonds.com/sites/default/files/Almanac\%202018. pdf

Baldi E, Cavani L, Margon A, Quartieri M, Sorrenti G, Marzadori C, Toselli M (2018) Effect of compost application on the dynamics of carbon in a nectarine orchard ecosystem. Sci Total Environ 637:918-925

Bar-Tal A, Yermiyahu U, Beraud J, Keinan M, Rosenberg R, Zohar D, Rosen V, Fine P (2004) Nitrogen, phosphorus, and potassium uptake by wheat and their distribution in soil following successive, annual compost applications. J Environ Qual 33:1855-1865

Binkley D, Hart SC (1989) The components of nitrogen availability assessments in forest soils. In: Stewart BA (ed) Advances in soil science, vol 10. Advances in Soil Science. Springer, New York, NY, pp 57-112

Blackshaw RE, Molnar LJ, Larney FJ (2005) Fertilizer, manure and compost effects on weed growth and competition with winter wheat in western Canada. Crop Prot 24(11):971-980

Borjesson G, Katterer T (2018) Soil fertility effects of repeated application of sewage sludge in two 30-year-old field experiments. Nutr Cycl Agroecosystems 112:369-385
Brown S, Kurtz K, Bary A, Cogger C (2011) Quantifying benefits associated with land application of organic residuals in Washington State. Environ Sci Technol 45:7451-7458

Canali S, Trinchera A, Intrigliolo F, Pompili L, Nisini L, Mocali S, Torrisi B (2004) Effect of long term addition of composts and poultry manure on soil quality of citrus orchards in Southern Italy. Biol Fertil Soils 40:206-210

Carlson RM (1996) Nutrients in the soil. In: Micke WC (ed) Almond production manual. University of California, Division of Agriculture and Natural Resources, Publication 3364, pp 116-120

Dey A, Srivastava PC, Pachauri SP, Shukla AK (2019) Release kinetics of some nutrients from a sandy loam soil treated with different organic amendments. Commun Soil Sci Plant Anal 50:2718-2732

Diacono M, Montemurro F (2010) Long-term effects of organic amendments on soil fertility. Rev Agron Sustain Dev 30:401-422

Ding F, Huang Y, Sun W, Jiang G, Chen Y (2014) Decomposition of organic carbon in fine soil particles is likely more sensitive to warming than in coarse particles: an incubation study with temperate grassland and forest soils in Northern China. PLOS One 9:95348

Eghball B (2002) Soil properties as influenced by phosphorusand nitrogen-based manure and compost applications. Agron. J. 94:128

Eusufzai MK, Fujii K (2012) Effect of organic matter amendment on hydraulic and pore characteristics of a clay loam soil. Open J Soil Sci 2:720-726

Feng W, Xu M, Fan M, Malhi SS, Schoenau JJ, Six J, Plante AF (2013) Testing for soil carbon saturation behavior in agricultural soils receiving long-term manure amendments. Can J Soil Sci 94:281-294

Forge T, Neilsen G, Neilsen D, Hogue E, Faubion D (2013) Composted dairy manure and alfalfa hay mulch affect soil ecology and early production of 'Braeburn' apple on M.9 rootstock. HortScience 48:645-651

Forte A, Fagnano M, Fierro A (2017) Potential role of compost and green manure amendment to mitigate soil GHGs emissions in Mediterranean drip irrigated maize production systems. J Environ Manage 192:68-78. https://doi.org/ 10.1016/j.jenvman.2017.01.037

Gannett M, Pritts MP, Lehmann J (2019) Soil amendments affect soil health indicators and crop yield in perennial strawberry. HortTechnology 29:179-188

Garcia-Gil JC, Ceppi SB, Velasco MI, Polo A, Senesi N (2004) Long-term effects of amendment with municipal solid waste compost on the elemental and acidic functional group composition and $\mathrm{pH}$-buffer capacity of soil humic acids. Geoderma 121:135-142

Gee GW, Bauder JW (1986) Particle-size Analysis. In: Klute A (ed) Methods of soil analysis part 1. Soil science society of America book series 5. Madison, Wisconsin, pp 383-411

Glover JD, Reganold JP, Andrews PK (2000) Systematic method for rating soil quality of conventional organic and integrated apple orchards in Washington State. Agri Ecosyst Environ 80(1-2):29-45. https://doi.org/10.1016/ S0167-8809(00)00131-6

Harmon ME, Silver WL, Fasth B, Chen H, Burke IC, Parton WJ, Hart SC, Currie WS (2009) Long-term patterns of mass 
loss during the decomposition of leaf and fine root litter: an intersite comparison. Glob Change Biol 15:1320-1338

Hart SC, Firestone MK, Paul EA (1992) Decomposition and nutrient dynamics of ponderosa pine needles in a Mediterranean-type climate. Can J For Res 22:306-314

Hartl W, Putz B, Erhart E (2003) Influence of rates and timing of biowaste compost application on rye yield and soil nitrate levels. Eur J Soil Biol 39:129-139

Hue NV, Liu J (1995) Predicting compost stability. Compost Sci Util 3:8-15

Jackson LE, Ramirez I, Yokota R, Fennimore SA, Koike ST, Henderson DM et al (2003) Scientists, growers assess trade-offs in use of tillage, cover crops and compost. Calif Agri 57(2). Retrieved from https://escholarship.org/uc/ item/8tv45119

Karami A, Homaee M, Afzalinia S, Ruhipour H, Basirat S (2012) Organic resource management: impacts on soil aggregate stability and other soil physico-chemical properties. Agric Ecosyst Environ 148:22-28

Kaur T, Brar BS, Dhillon NS (2008) Soil organic matter dynamics as affected by long-term use of organic and inorganic fertilizers under maize-wheat cropping system. Nutr Cycl Agroecosystems 81:59-69

Khalsa SDS, Brown PH (2017) Grower analysis of organic matter amendments in California orchards. J Environ Qual 46:649-658

Khalsa SDS, Smart DR, Muhammad S, Armstrong CM, Sanden BL, Houlton BZ, Brown PH (2020) Intensive fertilizer use increases orchard $\mathrm{N}$ cycling and lowers net global warming potential. Sci Total Environ 722:137889

Khalsa SDS, Hart SC, Brown PH (Accepted) Nutrient dynamics from surface-applied organic matter amendments on no-till orchard soil. Soil Use Manag

Leon A, Kohyama K, Takata Y, Yagi K, Umemiya Y, Ohkura T, Obara H (2015) Change in soil carbon in response to organic amendments in orchards and tea gardens in Japan. Geoderma 237-238:168-175

Lepsch HC, Brown PH, Peterson CA, Gaudin ACM, Khalsa SDS (2019) Impact of organic matter amendments on soil and tree water status in a California orchard. Agric Water Manag 222:204-212

Li Z, Liu C, Dong Y, Chang X, Nie X, Liu L, Xiao H, Lu Y, Zeng G (2017) Response of soil organic carbon and nitrogen stocks to soil erosion and land use types in the Loess hilly-gully region of China. Soil Tillage Res 166:1-9

Liu CA, Zhou LM (2017) Soil organic carbon sequestration and fertility response to newly-built terraces with organic manure and mineral fertilizer in a semi-arid environment. Soil Tillage Res 172:39-47

Martínez-Blanco J, Lazcano C, Christensen TH, Muñoz P, Rieradevall J, Møller J, Antón A, Boldrin A (2013) Compost benefits for agriculture evaluated by life cycle assessment. Rev Agron Sustain Dev 33:721-732

Mbau SK, Karanja N, Ayuke F (2015) Short-term influence of compost application on maize yield soil macrofauna diversity and abundance in nutrient deficient soils of Kakamega County Kenya. Plant Soil 387(1-2):379-394. https://doi.org/10.1007/s11104-014-2305-4

Mclean EO (2015) "Soil pH and lime requirement" Methods of soil analysis, pp 199-224. Wiley
Meyer GA, Keliher PN (1992) An overview of analysis by inductively coupled plasma-atomic emission spectrometry. In: Montaser A, Golightly DW (eds) Inductively coupled plasmas in analytical atomic spectrometry. VCH Publishers, New York, NY, pp 473-516

Minasny B, McBratney AB (2018) Limited effect of organic matter on soil available water capacity. Eur. J. Soil Sci. 69:39-47

Muhammad S, Sanden BL, Saa S, Lampinen BD, Smart DR, Shackel KA, DeJong TM, Brown PH (2018) Optimization of nitrogen and potassium nutrition to improve yield and yield parameters of irrigated almond (Prunus dulcis (Mill.) D.A. webb). Sci Hortic 228:204-212

Nicholson F, Bhogal A, Taylor M, McGrath S, Withers P (2018) Long-term effects of biosolids on soil quality and fertility. Soil Sci 183:89

Ozores-Hampton M, Stansly PA, Salame TP (2011) Soil chemical, physical, and biological properties of a sandy soil subjected to long-term organic amendments. J Sustain Agric 35:243-259

Parkinson R, Fuller M, Jury S, Groenhof A (1996) An evaluation of soil nutrient status following the application of (i) Cocomposted MSW and Sewage Sludge and (ii) Greenwaste to Maize. In: de Bertoldi M, Sequi P, Lemmes B, Papi T (eds) The science of composting. Springer, Netherlands, Dordrecht, pp 469-476

Paul EA (2016) The nature and dynamics of soil organic matter: plant inputs, microbial transformations, and organic matter stabilization. Soil Biol Biochem 98:109-126

Peck GM, Merwin IA, Thies JE, Schindelbeck RR, Brown MG (2011) Soil properties change during the transition to integrated and organic apple production in a New York orchard. Appl Soil Ecol 48:18-30

Powlson DS, Jenkinson DS (1981) A comparison of the organic matter, biomass, adenosine triphosphate and mineralizable nitrogen contents of ploughed and direct-drilled soils. J Agric Sci 97:713-721

Rible JM, Quick J (1960) Method S-3.1. In: Water soil plant tissue tentative methods of analysis for diagnostic purposes. Davis, University of California Agricultural Experiment Service. Mimeographed Report

Ryals R, Silver WL (2013) Effects of organic matter amendments on net primary productivity and greenhouse gas emissions in annual grasslands. Ecol Appl 23:46-59

Sah RM, Miller RO (1992) Spontaneous reaction for acid dissolution of biological tissues in closed vessels. Anal Chem 64(2):230-233

Sarker JR, Singh BP, Cowie AL, Fang Y, Collins D, Badgery W, Dalal RC (2018) Agricultural management practices impacted carbon and nutrient concentrations in soil aggregates, with minimal influence on aggregate stability and total carbon and nutrient stocks in contrasting soils. Soil Tillage Res 178:209-223

Storie RE, Weir WW (1953) Generalized soil map of California. California agricultural experiment station extension service. Manual 6

Tahovská K, Čapek P, Šantrůčková H, Kopáček J (2018) In situ phosphorus dynamics in soil: long-term ion-exchange resin study. Biogeochemistry 139:307-320

Tahovská K, Šantrůčková H, Kopáček J (2010) Nitrogen availability in Norway spruce forest floor - the effect of 
forest defoliation induced by bark beetle infestation. Boreal Environ Res 15:552-564

Torn MS, Trumbore SE, Chadwick OA, Vitousek PM, Hendricks DM (1997) Mineral control of soil organic carbon storage and turnover. Nature 389:170-173

Vrugt JA, Hopmans JW, Šimunek J (2001) Calibration of a twodimensional root water uptake model. Soil Sci Soc Am J 65:1027-1037

Wang Y, Lin Y, Chiu PC, Imhoff PT, Guo M (2015) Phosphorus release behaviors of poultry litter biochar as a soil amendment. Sci Total Environ 512-513:454-463

Warren M (1996) Almond Production Manual. University of California. Division of Agriculture and Natural Resources. Publication 3364
Weil R, Brady N (2017) The nature and properties of soils, 15th edn. Pearson Education

Zhao Y, Wang P, Li J, Chen Y, Ying X, Liu S (2009) The effects of two organic manures on soil properties and crop yields on a temperate calcareous soil under a wheat-maize cropping system. Eur J Agron 31:36-42

Publisher's Note Springer Nature remains neutral with regard to jurisdictional claims in published maps and institutional affiliations. 